\title{
脳磁図システム用液体ヘリウム再循環システムの 開発と運転記録
}

\author{
正員 川勝真喜, 小林宏一郎, 内川義則, 斎藤正男, 小谷誠（東京電機大学） \\ The development and the operation records of a Liquid Helium \\ Recirculation System for a Magnetoencephalograph Measurement system
}

\author{
Masaki Kawakatsu, Koichiro Kobayashi, Yoshinori Uchikawa, Masao Saito, Makoto Kotani \\ (Tokyo Denki University)
}

\begin{abstract}
We have developed a helium collection and re-liquefaction system for a MEG measurement system, and used the system applying to a 195 channel SQUID system. The helium purchase quantity became half the amount in our former report. However, this SQUID system has the large amount of consumption of helium compared with other MEG systems. So, we applied the re-liquefaction system to 122-channel SQUID system (Neuromag122 $2^{\mathrm{TM}}$ ) which used the general amount of the helium (about 100 liters/week). The helium purchase quantity became less than $1 / 4$, and the whole expenses of cooling also became an about $43 \%$ decrease.
\end{abstract}

キーワード：液体ヘリウム、運転コスト、ヘリウムの再利用、運転記録

\section{1. はじめに}

限られた資源であるへリウムの効率的な利用のため我々は これまでに低ノイズの脳磁図システム用へリウム再液化・循環 システムの開発を行ってきた[1]。このシステムによって、生体 磁気計測においては、従来大気中一放出してしまっていた ガス化したへリウムを再度液化することによりへリウムの購入 量を半分にすることに成功し、その有効性を明らかにした。さ らに、このシステムは汎用性を持って作られており対象とする 生体磁気計測システムを選ばない。これまでは、東京電機大 学超電導応用研究所に設置されているべクトル型 195 チャ ネル全頭型脳磁界計測システムに適用したが、今回は先の 報告よりガスバックを増設するなど更にシステムを増設し、多 くの研究施設で利用されているNeuromag 社製の 122 チヤ
ネル全頭型脳磁界計測システムに再循環システムを適用し た。その結果、更にへリウムの購入量は $1 / 4$ 以下となり、ラン ニングコストも約 $43 \%$ 减となった。

\section{2. システム}

システムの基本構成は前回の報告と変わらないのでここで は概要を述べる。図 1 に示されるようにガスの回収、精製(不 純物の除去)、再液化のブロックからなる。回収には特殊ゴム を利用したガスバックを2台用いた。2つのガスバックの容量 は合せて $28 \mathrm{~m}^{3}$ である。水分除去器は電子エアードライヤー (八重崎空圧 $\mathrm{EAD}-70$ )、モレキュラーシーブ $400 \mathrm{~g}$ を用いた 乾燥剤より露点温度が-60度になるよう水分除去を行った。精 製器は、冷凍機、2つの吸着器 (活性炭) 等からなる。2つの吸 着器はへリウム以外の不純物を吸着し、第 1 吸着器は-90〜

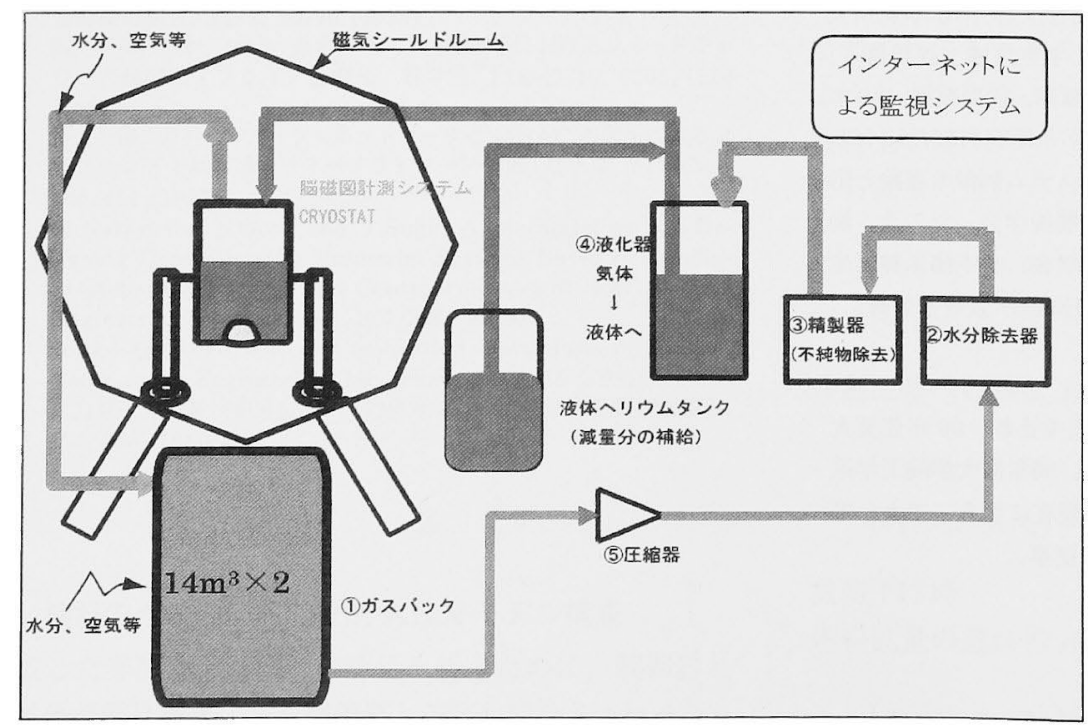

Figure 1. Scheme of the helium collection and liquefaction system. The system consists of the following,

(1) two Gas-bags,

(2) air dryer,

(3) helium refiner with a refrigerator,

(4) liquefaction system with two refrigerators, (5) a compressor for circulation. 
$-120^{\circ} \mathrm{C}$ 程度、第 2 吸着器は $-210^{\circ} \mathrm{C}$ 以下に冷却される。液化器 は2つの冷凍機、へリウムタンク(約 100 リットル)などからなる。 冷谏機の1つは熱シールドを冷やし、約 $80 \mathrm{~K}$ まで泠却する。ま た、もう一方の冷凍機はへリウムタンク内に設置し $4.3 \mathrm{~K}$ に椧却 することにより、精製されたへリウムガスを液化するものであ る。

また、今回からインターネットを通じて研究所外からシステム の状態をモニタリングできるようにした。このことにより、システ ム管理者はどこにいてもシステムを監視することができる。

\section{3. 生体磁気システム}

Neuromag122 チャネルシステムは蒸発量が約 8 リッル/日 と少ないが、へリウムガスの排気部分にシリコンチューブ等を 用いているため、不純物の混入が若干多い。循環システムを 利用しない場合、一週間に約 100 リットルの液体へリウムを消 費する。一方の 195 チャネルベクトルシステムは 4 日問で 100 〜 125 リットルの液体へリウムを使う生体磁気計測システムの 中でも大型のものである。デュア自体の蒸発量は約 17 リトル ノ日、それ以外はトランスファー時の蒸発により消費される。

\section{4. 結果}

例として表1に Neuromag122 チャネルシステム(平成 13 年 12 月)と 195 チャネルベタトルシステム (平成 12 年 9 月の一 ケ月間)の一ヶ月間の運転記録を表 1 に、コストの試算を表 2 ,
3に示す。195チャネルベクトルシステムでは、購入量が半減、 コストは試算で約 $38 \%$ の堿となった。一方、Neuromag 122 チ ヤネルシステムでは購入量は $1 / 4$ 以下に、コストは約 $43 \%$ 減と なった。

\section{5. まとめ}

開発した液体へリウム循環システムを多くの機関で利用され ている Neuromag122 チャネルシステムに適用して液体へリ ウムの購入量が 1/4 以下となることが示された。195 チャネル システムとの差は主に液体へリウムの蔈発量の差と増設され たガスバックによるトランスファー時のへリウムガスの損失が減 ったことによると考えられる。また、現在のへリウムのロスは、ト ランスファー時にトランスファーチューブ等をへリウムガスでパ ージする際や精製器再生時に精製器内に残留してしまうへり ウムガスが主であると考えられる。これらは運用の方法で更に 減らすことが可能であると考えられる。

(平成 14 年 2 月 7 日受付)

$$
\text { 文献 }
$$

[1] 川勝真喜、小林宏一郎、他: 脳磁図システム用ヘリ ウム再液化・循環システムの開発, 電学論 $\mathrm{C}, 122,1$, $66-70,(2002)$

Table.1 An Operation record

\begin{tabular}{|c|c|c|}
\hline 装置 & ベクトル 195 チャネルシステム & Neuromag122 チヤネルシステム \\
\hline 期間 & 35 日間 & 31 日間 \\
\hline 液化量 & 約 490 リットル（0.58 リットル/時閒） & 約 360 リットル(0.47 リットル/時間) \\
\hline 精製器再生時間 & $\begin{array}{l}\text { 計 } 145 \text { 時間 } \\
\text { (再生時間を考慮に入れた平均の再液化 } \\
\text { 量は } 0.71 \text { リットル/時間) }\end{array}$ & $\begin{array}{l}\text { 計 } 150 \text { 時間 } \\
\text { (再生時間を考慮に入れた平均の再液化 } \\
\text { 量は } 0.59 \text { リットル/時間) }\end{array}$ \\
\hline $\begin{array}{l}\text { 液化器からのトランスファ } \\
\text { 一回数 }\end{array}$ & 6 回 (平均 72 リットル) & 8 回 (平均 41 リットル) \\
\hline $\begin{array}{l}\text { ベッセルからのトランスフア } \\
\text { 一回数 }\end{array}$ & 5 回 (毎回 100 リットル) & 1 回(70 リットル) \\
\hline
\end{tabular}

Table.2 An estimation of cost for Neuromag122 whole-cortex MEG system

\begin{tabular}{|c|c|c|c|}
\hline & 液体へリウム & 電気料金ほ力 & 合計 \\
\hline 再液化システム導入前 & 400 リットル(約 400k 円) & 0 & 約 $400 \mathrm{k}$ 円 \\
\hline 再液化システム導入後 & 70 リットル(約 70k 円) & $\begin{array}{l}\text { 冷凍器等 } 12 \mathrm{~kW} / \mathrm{h} \\
\text { 冷却水ポンプ } 2 \mathrm{~kW} / \mathrm{h} \\
\text { (約 } 146 \mathrm{k} \text { 円) } \\
\text { 冷凍機の保守費 } 12 \mathrm{k} \text { 円 }\end{array}$ & 約 $228 \mathrm{k}$ 円 \\
\hline
\end{tabular}

Table.3 An estimation of cost for vector 195 channel system

\begin{tabular}{|l|l|l|l|}
\hline & 液体ヘリウム & 電気料金ほか & 合計 \\
\hline 再液化システム導入前 & 900 リットル(約 900k 円) & 0 & 約 $900 \mathrm{k}$ 円 \\
\hline 再液化システム導入後 & 400 リットル(約 400k 円) & $\begin{array}{l}\text { 冷凍器等 } 12 \mathrm{~kW} / \mathrm{h} \\
\text { 冷却水ポンプ } 2 \mathrm{~kW} / \mathrm{h} \\
\text { (約 146k 円) } \\
\text { 冷凍機の保守費 } 12 \mathrm{k} \text { 円 }\end{array}$ & 約 $560 \mathrm{k}$ 円 \\
\hline
\end{tabular}

